\title{
Development and optimization of fast ablative pyrolysis technology in Ukraine
}

\section{Vitalii Zubenko,}

\section{Alex Epik,}

\section{Viacheslav Antonenko}

Institute of Engineering Thermophysics of National Academy of Sciences, Scientific Engineering Centre "Biomass", Zhelyabova St. 2a, 03067,

P.O. Box 66, Kyiv-67, Ukraine

Email: zubenko@biomass.kiev.ua; epik@biomass.kiev.ua; antonenko@biomass.kiev.ua
The article contains the aggregated results of the development and optimization of laboratory installation for ablative fast pyrolysis performance with productivity $1-4 \mathrm{~kg} /$ hour on final products. The experimental data on a series of experiments (>60) with analysis of the influence of a certain range of input parameters on the bio-oil yield and qualitative parameters of output products is presented. The optimization of installation regimes and input parameters for bio-oil yield maximization for different biomass types is performed. It was found that the ratio of three output products is not always optimal maximizing bio-oil yield with respect to energy yield in the products. The maximum achieved bio-oil yield is $51 \%$, with the average level of $44 \%$ (by mass rated to the input products). It is revealed that the final bio-oil yield depends mainly on temperature in the reactor, time of biomass particles existence in the reactor, and biomass fraction. The mass distribution for pyrolysis by-products (pyrogas and biochar) is dependent on the initial moisture content of biomass and organization of the condensation process of bio-oil. The energy balance of installation demonstrates the average efficiency of the pyrolysis process on the level of $65 \%$ (with maximum $98 \%$ ) and could be increased to $90 \%$ average with a simple reconstruction of installation. On the basis of obtained laboratory data, the scaling of the installation was performed with the development of a commercial prototype with the productivity of $50 \mathrm{~kg} /$ hour. On the basis of obtained technical data, the assessment of economic indicators of bio-oil and biochar production with large sized mobile installation has been performed demonstrating a good commercial feasibility of the installation performance.

Keywords: fast ablative pyrolysis, screw reactor, bio-oil, biochar, pyrogas, pyrolysis energy efficiency 


\section{INTRODUCTION}

The latest energy policies of the EU-28 and OECD countries are aimed at setting the ambitious targets on the development of renewable energy and bioenergy. As for Ukraine, the main feature of energy supply is that approximately half of energy resources (mainly natural gas for heating and industrial purposes) is imported. The price of natural gas has increased significantly over the last five years and is expected to grow further. The real and practical alternative to natural gas is the utilization of renewable energy sources, including biomass.

There are various commercialized technologies of raw biomass utilization, out of which the most widespread and currently economically feasible is direct combustion in boilers. Despite its cheapness and comparative simplicity, in some cases direct biomass combustion is not an appropriate technology for specific industrial sites. For example, it is often technically impossible to install a biomass boiler on site or when there is a necessity for distant transportation of biofuel. In such specific cases, the technologies of biomass gasification and pyrolysis can make sense as they provide a higher output energy density per mass unit of fuel in comparison with raw solid biomass. Thus, pyrolysis could be considered one of the ways for effective utilization of biomass residues increasing its energy concentration.

According to $[1,2]$, bio-oil is the cheapest liquid which can be produced from biomass. Despite some advantages, good prospects of development and pilot installations already in place, fast pyrolysis technology is not yet as commercial as direct combustion and has unresolved features. There is a number of technical and process organization problems to be solved [2-4], and this article is aimed to contribute to this.

\section{COMPARISON OF THE MAIN PYROLYSIS TECHNOLOGIES, ADVANTAGES OF FAST ABLATIVE PYROLYSIS TECHNOLOGY WITH SCREW REACTOR}

The pyrolysis technologies are represented by various technical realization approaches, namely: ablative pyrolysis, fluidized bed pyrolysis, cir- culating fluidized bed pyrolysis, twin fluidized bed pyrolysis, entrained reactor pyrolysis (in the flow), and rotating cone reactor. Each of them has its weak and strong sides and energy performance indicators. A comparison of the various pyrolysis technologies with respect to laboratory, pilot, demonstration and commercial-based biomass fast pyrolysis units that currently exist in the world has been done by specialists of BTGBTL group [5]. The modified RCR installation operated by BTG-BTL group (in the Netherlands) working on the principle of fast pyrolysis with combination of ablative and rotating cone reactor. The main advantages of named technology in comparison with other pyrolysis technologies are high yield of bio-oil, high calorific value of pyrogas, ability to produce electricity, and low amount of solid particles in bio-oil (0.01\%wt.).

Presently, two types of ablative reactors are known: based on rotating blades and based on a rotating cone. In the previous works $[6,7]$ it was demonstrated the advantages of alternative "third" type of fast pyrolysis based on the cone screw. It was proven that the pyrolysis reactor of own new design is more efficient with respect to the velocity of ablation, easier scaling and potentially lower overall cost of construction in comparison with the other types $[8,9]$.

The construction and primary design of ablative fast pyrolysis laboratory installation were presented in [8]. Experiments have shown that the laboratory installation worked steadily for 180 minutes. Constant yields of bio-oil at the level of about $50 \%$ by weight were achieved due to the determination (on the basis of previous test launches) and proper maintenance of optimal operating conditions of the laboratory installation during the experiment.

The conditions of the conducted experiments are summarized on Fig. 1. A series of experiments was carried out with the following ranges of parameters $[6,10]$ :

- Input product consumption: $0.5-4.5 \mathrm{~kg} /$ hour;

- Temperature on the outside reactor surface: $525-650^{\circ} \mathrm{C}$;

- Velocity of biomass particle in the reactor: $0.8-1.2 \mathrm{~m} / \mathrm{s}$;

- Time-frame of biomass particle existence in the reactor: $0.6-0.75 \mathrm{~s}$. 


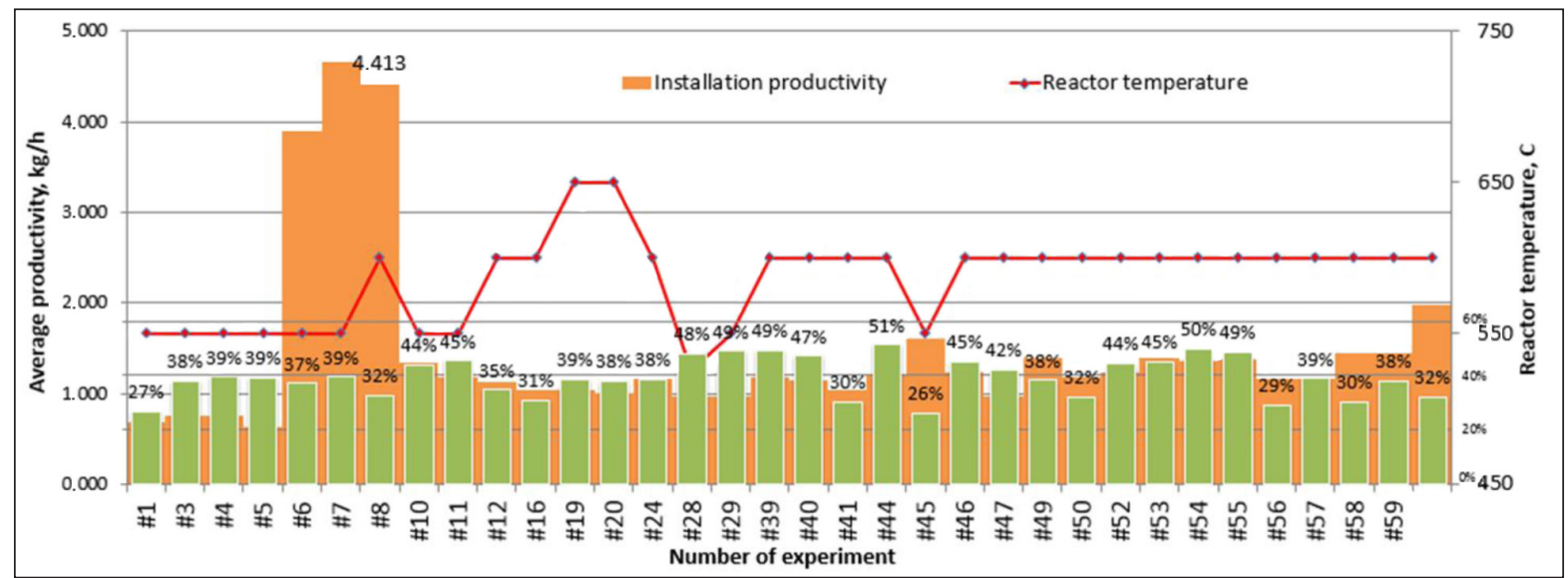

Fig. 1. Aggregated data for 60 experiments with indication of input parameters and respective bio-oil yield

\section{DESCRIPTION OF THE EXPERIMENTAL SETUP AND METHODOLOGY}

The schematic diagram of the laboratory experimental setup developed by authors in the Insti- tute of Engineering Thermophysics of National Academy of Sciences of Ukraine is presented in Fig. 2. The main part of the setup is the ablative reactor zone which is designed with division of three separate zones to provide the necessary

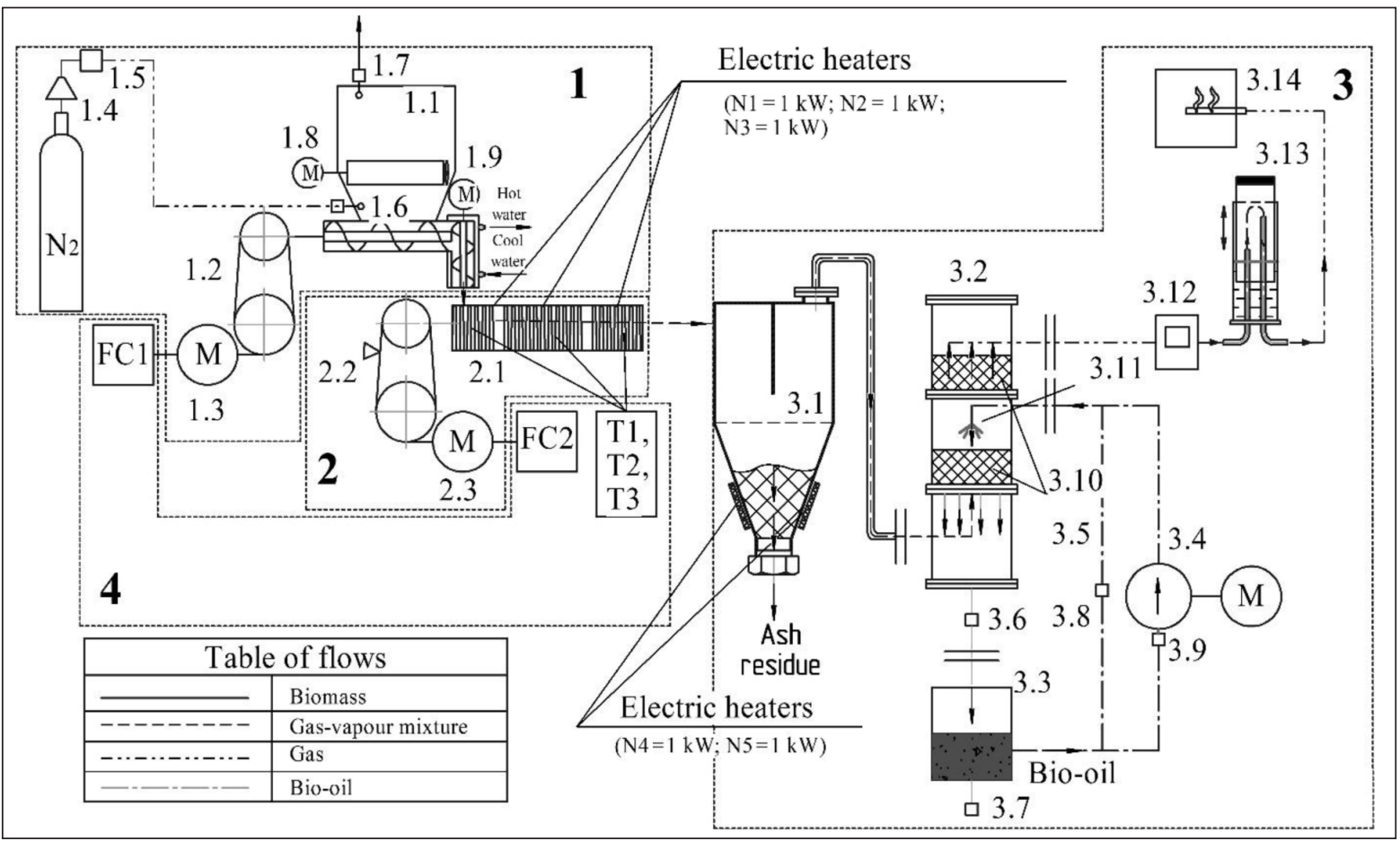

Fig. 2. Principal scheme of the experimental installation of fast pyrolysis of biomass: 1 - raw material feeding system, 1.1 - screw feeder of raw materials with hopper, 1.2 - V-belt drive transmission of screw feeder, 1.3 - gear motor, 1.4 - gas reducer, 1.5 - gas regulator, 1.6, 1.7 - valves, 1.8 - gear motor of hopper agitator drive, 1.9 - gear motor of vertical pipe screw drive; 2 - reactor block, 2.1 - reactor with screw, 2.2 - V-belt drive transmission of reactor screw, 2.3 - motor; 3 - system of steam-and-gas cleaning and pyrolysis gases utilization, 3.1 - settling chamber, 3.2 - scrubber, 3.3 - tank for bio-oil collecting, 3.4 - pump, 3.5 - bypass (pump regulation of cooling liquid feed velocity), 3.6-3.9 - stop valves, 3.10 - Raschig rings, 3.11 - flow nozzle, 3.12 - pyrolysis gas flowmeter, 3.13 - gasholder, 3.14 - burner for pyrolysis gas combustion; 4 - power supply and control unit 
temperature levels and their proper distribution between the zones, namely:

1) zone of biomass preheating to achieve the necessary temperature;

2) zone of the pyrolysis process;

3) zone of pyrolysis products removal.

There are three electric heaters with $1 \mathrm{kWel} \mathrm{ca}$ pacity each on the external surface of the reactor. A microprocessor temperature controller controls heaters by using signals from thermocouples that are fixed on the external surface of the reactor body. The maximum reactor temperature which the heater can provide is $650^{\circ} \mathrm{C}$. The reactor body is covered with insulating materials to provide at maximum extent the adiabatic conditions of the experiment.

Experiments have shown that the laboratory installation worked steadily for 180 minutes. Constant yields of bio-oil at the level of about $50 \%$ by weight were achieved due to the determination (on the basis of previous test launches) and proper maintenance of the optimal operating conditions of the laboratory installation during the experiment.

For the experiments, different samples of wood sawdust with moisture content of $4 \%$ by weight and with particle sizes of $0.5 \ldots 0.7 \mathrm{~mm}, 0.5 \ldots 1.0 \mathrm{~mm}$, and $0.5 \ldots 5 \mathrm{~mm}$ and bulk density of $160 \mathrm{~kg} / \mathrm{m}^{3}$, $138 \mathrm{~kg} / \mathrm{m}^{3}$, and $120 \mathrm{~kg} / \mathrm{m}^{3}$, correspondingly, were used as raw material. The hopper and the vertical pipe of the feeder were equipped by the agitator and screw, which are driven by gear motors, to avoid the hovering of raw material.

The order of experiments was as follows: Portions of sampled of biomass of $3 . .3 .5 \mathrm{~kg}$ weight each were loaded into the hopper, which was sealed to prevent leakage of pyrolysis gas in the opposite direction and to prevent high gas concentration in the laboratory. Before the experiment, nitrogen was injected in the lower pipe of the hopper for $20 . .25$ minutes at a constant flow rate of $0.117 \mathrm{~m}^{3} / \mathrm{h}$ for purging of hopper and the path from the reactor to the scrubber of the bio-oil condensation system. The air is forced out from the hopper by nitrogen and taken out through the upper pipe and the burner to the environment. Then diesel oil (3 liters) was measured out and poured into the storage tank with the purpose to initiate condensation process prior to bio-oil obtaining.

After all these manipulations, the electric heaters of the reactor and the settling chamber were turned on and the installation components were heated up to the required operating temperatures for the certain experiment. The regulation of the reactor temperature was carried out by signals of thermocouples fixed on the external surface of the reactor, taking into account the temperature difference between the outer and inner surfaces, depending on the estimated installation productivity. Temperature fixed by the controller equals the sum of the required raw material temperature in the reactor and the calculated thermal gradient in the reactor wall. During experiments, the temperature of the external wall of the reactor was maintained at $550 \ldots 650^{\circ} \mathrm{C}$, the settling chamber temperature at $50^{\circ} \mathrm{C}$, while the rate of temperature increase has to be maintained not higher than at $2^{\circ} \mathrm{C} /$ hour. Simultaneously, the system of temperatures measuring and recording system, which includes multi-gauge and PC, was turned on. The circulating pump was turned on to supply diesel for the scrubber spraying after installation desired temperatures stabilization.

The drivers of the hopper agitator and screw of vertical pipe feeder were turned on to ensure stable operation of the feeding system. Current frequencies, which are matched to the corresponding screw rotation speed, were set by the frequency converters, which drive the electric motors of the reactor and the feeding screw, on the control panel.

The conditions of the chosen experiments are summarized in Table 1.

Table 1. Typical conditions and results of experiments (chosen experiments)

\begin{tabular}{c|c|c|c|c|c}
\hline Characteristic & \multicolumn{5}{|c}{ Number of chosen experiments } \\
\cline { 2 - 6 } & $\# \mathbf{2 8}$ & $\mathbf{\# 2 9}$ & $\# \mathbf{7}$ & $\# \mathbf{1 0}$ & $\# \mathbf{5 7}$ \\
\hline Temperature of the reactor external surface $\left({ }^{\circ} \mathrm{C}\right)$ & 550 & 600 & 550 & 550 & 650 \\
\hline Temperature of the settling chamber $\left({ }^{\circ} \mathrm{C}\right]$ & \multicolumn{5}{|c}{50} \\
\hline Flow rate of nitrogen for purging $\left(\mathrm{m}^{3} / \mathrm{h}\right)$ & 0.117 \\
\hline
\end{tabular}


Table 1. (continued)

\begin{tabular}{|c|c|c|c|c|c|}
\hline \multirow{2}{*}{ Characteristic } & \multicolumn{5}{|c|}{ Number of chosen experiments } \\
\hline & \#28 & $\# 29$ & \#7 & $\# 10$ & $\# 57$ \\
\hline Size of raw material particles (mm) & $0.5 \ldots 1$ & $0.5 \ldots 1$ & $0.5 \ldots 0.7$ & $0.5 \ldots 5$ & $0.5 \ldots 5$ \\
\hline Residence time of biomass particles in the reactor (s) & \multicolumn{5}{|c|}{1.0} \\
\hline Moisture of raw material (\%) & \multicolumn{5}{|c|}{4} \\
\hline Experiment time (min) & 180 & 130 & 45 & 120 & 180 \\
\hline Temperature of cooling liquid $\left({ }^{\circ} \mathrm{C}\right)$ & 12 & 14 & 10 & 12 & 13 \\
\hline Flow rate of cooling liquid $\left(\mathrm{m}^{3} / \mathrm{h}\right)$ & \multicolumn{5}{|c|}{0.18} \\
\hline Weight of processed biomass $(\mathrm{kg})$ & 2.88 & 2.57 & 3.49 & 2.68 & 3.13 \\
\hline Weight of carbon residue (kg) & 0.7 & 0.432 & 1.47 & 0.998 & 0.78 \\
\hline Yield of carbon residue (\% wt.) & 24.3 & 16.8 & 42 & 37 & 24.9 \\
\hline Weight of bio-oil (kg) & 1.408 & 1.262 & 1.38 & 1.18 & 1.21 \\
\hline Yield of bio-oil (\% wt.) & 48.9 & 49.1 & 39 & 44 & 38.6 \\
\hline Density of bio-oil $\left(\mathrm{kg} / \mathrm{m}^{3}\right)$ & 1110 & 1190 & 1140 & 1020 & 1105 \\
\hline Higher calorific value of bio-oil (MJ/kg) & $\mathrm{n} / \mathrm{d}$ & 13.77 & \multicolumn{3}{|c|}{ not determined } \\
\hline Gases yield and losses (on balance) (\% wt.) & 26.8 & 34.1 & 18 & 19 & 36.5 \\
\hline Installation productivity of biomass processing $(\mathrm{kg} / \mathrm{h})$ & 0.96 & 1.186 & 4.65 & 1.338 & 1.044 \\
\hline
\end{tabular}

\section{RESULTS OF THE EXPERIMENTS AND EFFICIENCY INDICATORS}

The obtained experimental data showed that the average bio-oil yield for chosen experiments (with exclusion of failed ones) is $44 \%$ (Fig. 3). The maximum bio-oil yield is $51 \%$ with the outside reactor temperature $600^{\circ} \mathrm{C}$, input product consumption $1.2 \mathrm{~kg} /$ hour, and velocity of biomass particles $1.2 \mathrm{~m} / \mathrm{s}$. If the temperature in the reactor is increased higher than $650^{\circ} \mathrm{C}$, the rapid increasing of pyrogas yield is observed (up to $60 \%$ by mass of output product) - the process is transforming from pyrolysis towards gasification-like process. In case of increasing of the time-frame of particle existence in the reactor more than $0.75 \mathrm{~s}$, the rapid increasing of biochar yield is observed (up to $50-60 \%$ by mass of output product) - the process tends to be more like the torrefication process.

The energy and mass balance for the laboratory installation was made to assess the right performance of installation. Input energy consists of energy in biofuel on the basis of net calorific

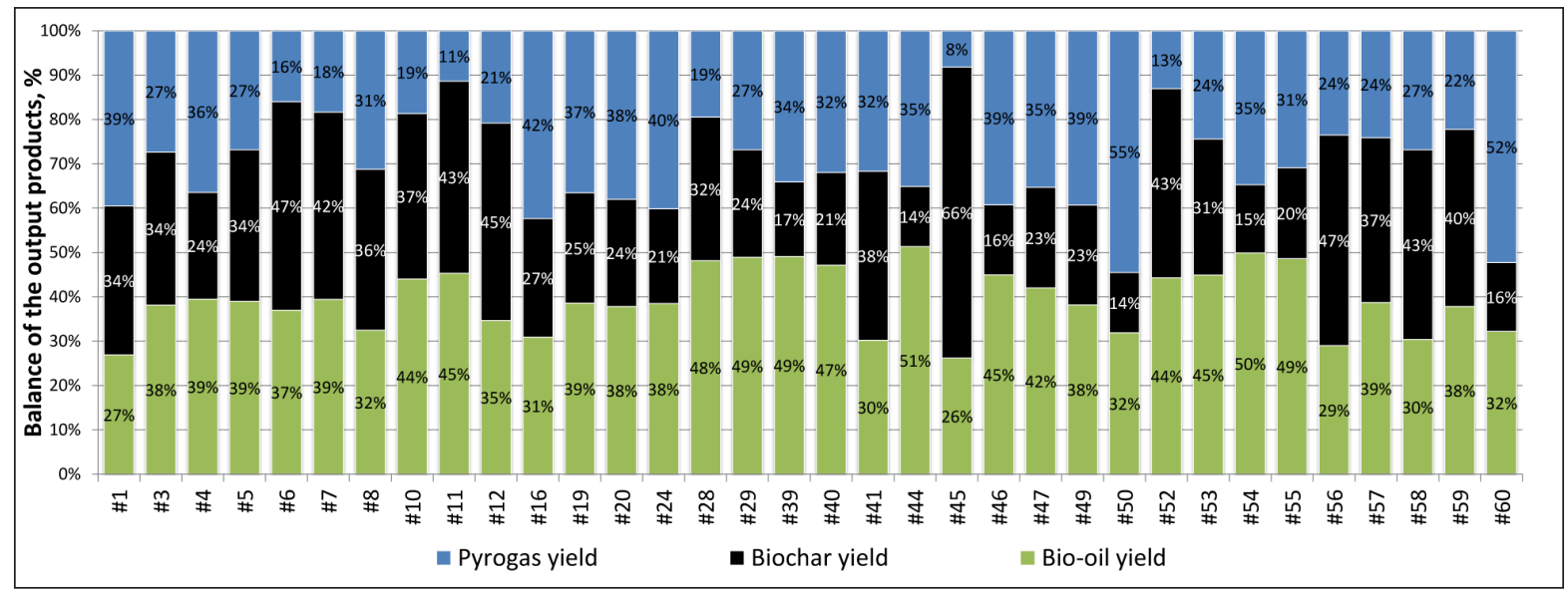

Fig. 3. Balance of output products of pyrolysis process for the chosen series of experiments 
value (Q1) and additional energy supplied from the reactor heating system (Q2) - see Fig. 4a. The output energy consists of energy in output products on the basis of net calorific value of each product $(\mathrm{Q} 3)$ and heat losses $(\mathrm{Q} 4)$.

Figure $4 \mathrm{~b}$ demonstrates the values of mass balance for a real experiment with the maximum bio-oil yield. It could be seen that $0.9 \mathrm{~kg}$ of input biofuel provides $0.316 \mathrm{~kg}$ of pyrogas, $0.122 \mathrm{~kg}$ of biochar, and $0.46 \mathrm{~kg}$ of bio-oil. The mass balance shows that the quantities of input and output products are equal. The inert gas $\mathrm{N}_{2}$ (used to prevent oxygen penetration to the system) is circulating in the system on a constant basis without changes in mass balance. The heat losses are caused in different zones of installation: condensation system, reactor surface through insulation, vertical tube from the feeding zone to the reactor zone, the tail-end zone where pyrogas is produced.

Figure 5 demonstrates the values of energy efficiency of installation for the chosen series of experiments calculated according to the energy balance approach Q3/(Q1 + Q2). It could be seen that the maximum energy efficiency of installation achieves 94\% (for experiments No. 6-8). Such high efficiency is observed because installation worked at the nominal designed capacity with the respective high input product consumption - more than $4 \mathrm{~kg} /$ hour. The lowest energy efficiency of installation is $50 \%$ (experiment No. 1-4) because the first

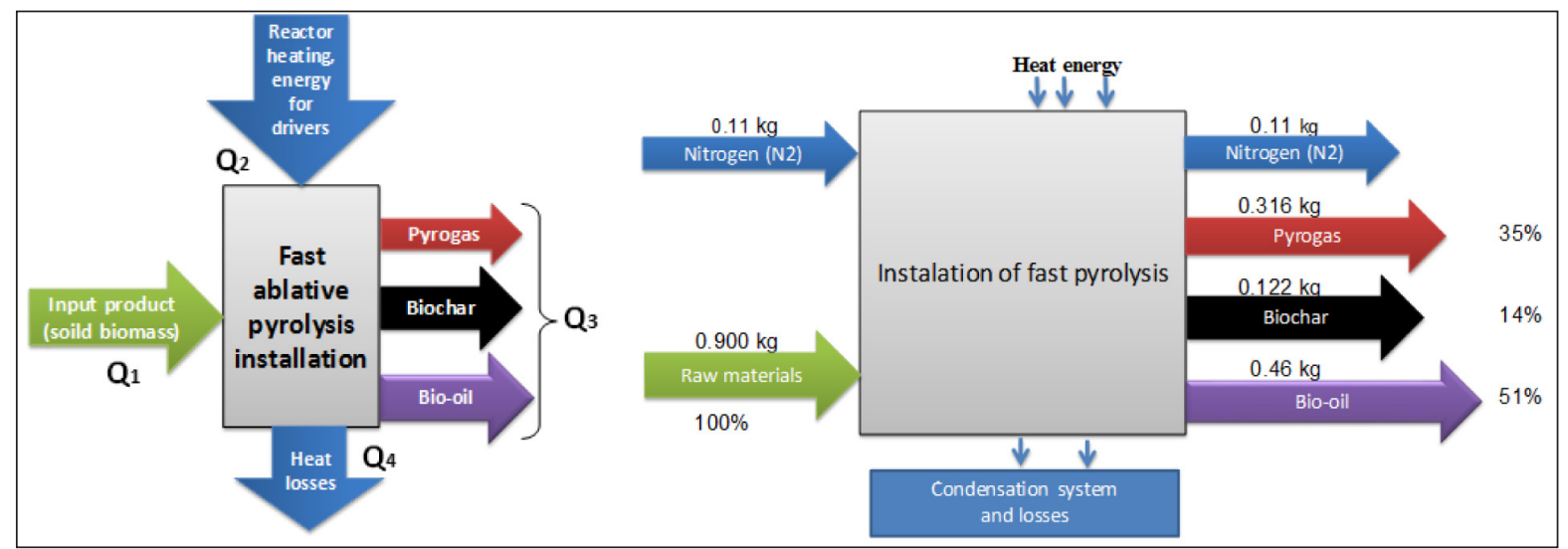

Fig. 4. The energy and mass balance for the laboratory installation

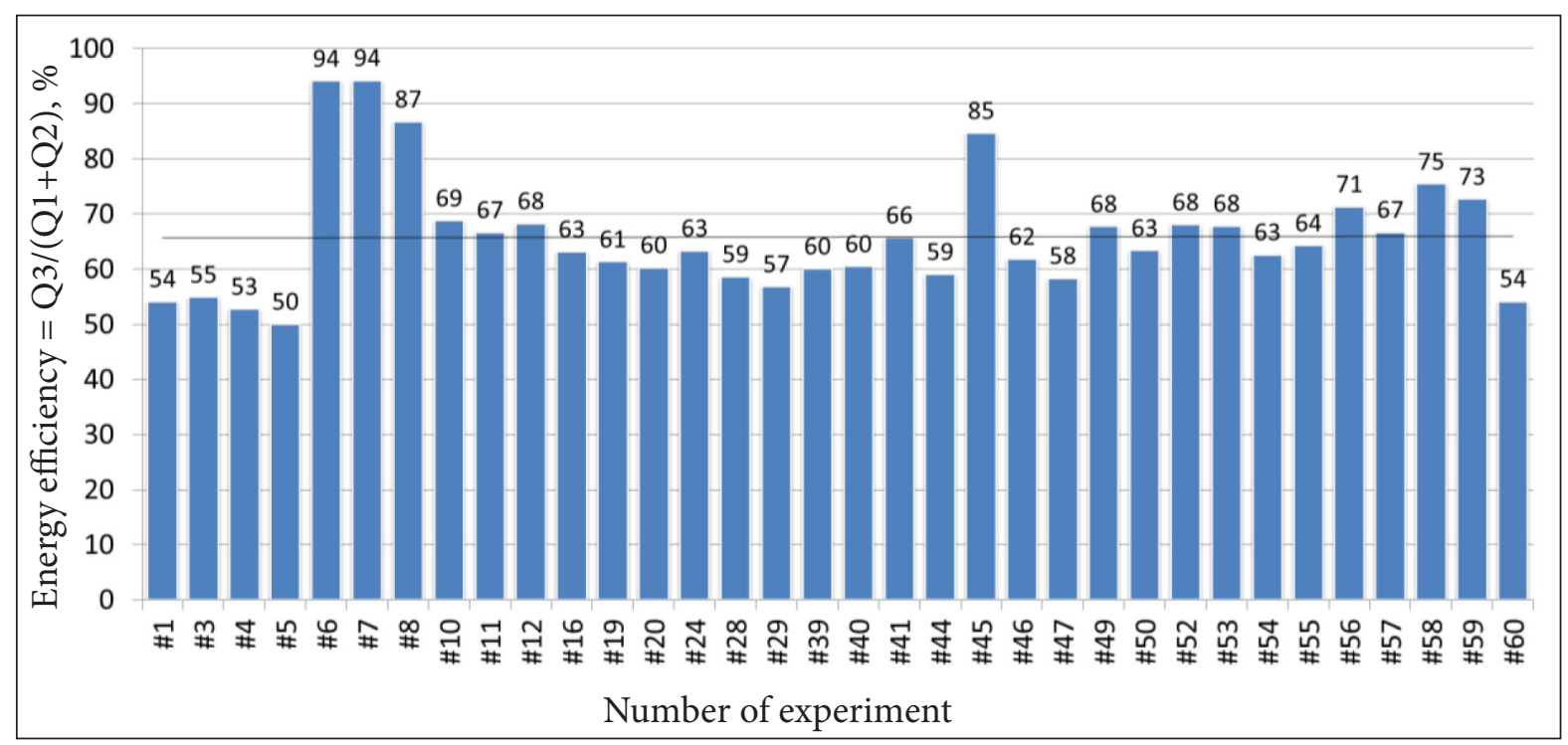

Fig. 5. Energy balance of installation 
experiments were performed for tuning the regimes of installation and were not much representative with respect to the energy efficiency indicator.

The average energy efficiency of installation for the chosen series of experiments is 65\% which is quite a low indicator. Therefore, it is necessary to somehow increase it. Currently, the simplest method is to return heat losses from the vertical tube between the feeding zone and the reactor zone to the setting chamber between the reactor zone and the condensation zone. According to the calculation it is expected that such modification can provide up to $10 \%$ increase of average energy efficiency (see Fig. 6).

Another method to improve energy efficiency is utilization of pyrogas for own purposes of installation (heating of the reactor zone) which also reduce electricity consumption. This could be done by means of its combustion in a separately designed burner and subsequent heating of the reactor by hot $\left(800-1000^{\circ} \mathrm{C}\right)$ combustion gases. The amount of heat from pyrogas combustion is enough to provide $40-100 \%$ (average $60 \%$ ) of own needs of installation in heating (see Fig. 7).

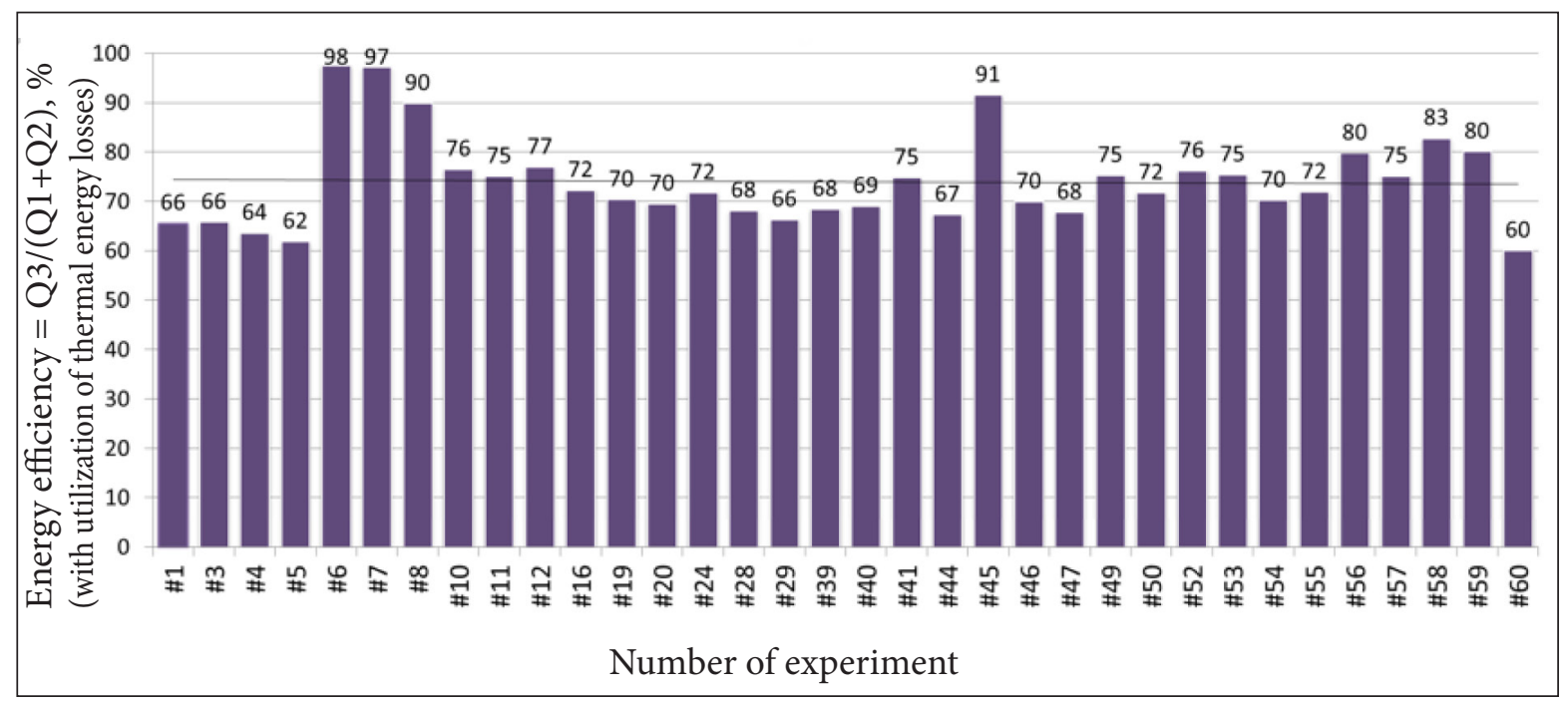

Fig. 6. Energy balance of installation with utilization of heat losses from feedstock system

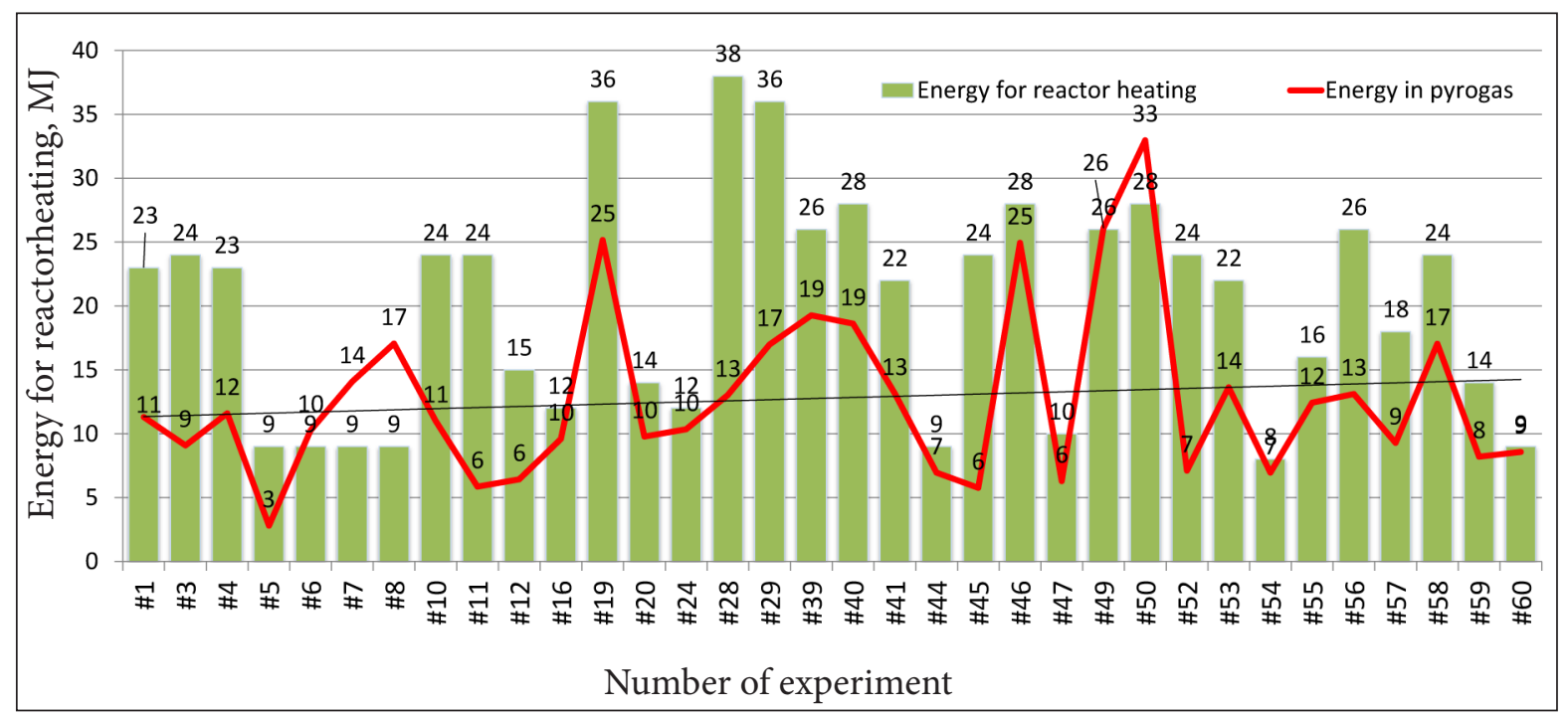

Fig. 7. Reactor heating from own-produced pyrogas utilization 


\section{ASSESSMENT OF ECONOMIC INDICATORS FOR COMMERCIAL-SIZE INSTALLATION FOR BIO-OIL AND BIOCHAR PRODUCTION}

To assess the economic feasibility, the commercial-scale mobile pyrolysis installation with the capacity of $500 \mathrm{~kg} / \mathrm{hour}$ by input product is considered. As the main advantage of cone screw fast ablative pyrolysis technology is simple scaling, such large installation could be scaled from the considered laboratory installation without principal technical modifications. The most important peculiarities of the large-scale installation are the following:

- Energy efficiency, mass and energy balance, yield, qualitative indicators of output products, optimal regime parameters of operation are the same as for the represented laboratory installation;

- Pyrogas is used as a primary energy source for reactor heating covering $60 \%$ of heat energy needed for reactor heating according to the energy balance data for the laboratory installation;

- Operation is performed nearby the source of input biomass product and the obtained biooil and biochar are to be sold on site as fuel for further combustion in the oil/coal boiler houses and/or CHPs.

The total capital costs (CAPEX) needed for fast ablative pyrolysis installation construction taking into account all necessary main and auxiliary equipment are 1.25 million EUR according to the commercial propositions of local producers of components and the authors' own assessment on the basis of existing operational laboratory installation and average-size (50 kg/hour) commercial mobile installation. The technical characteristics and operational expenses of commercial-size installation are represented below in Table 2.

The total cost of bio-oil from biomass is assessed on the level of $38.9 € / t$ excl. VAT with respective input product ${ }^{1}$ cost of $13 \mathrm{EUR} / \mathrm{t}$. The total cost of produced biochar will be $46.3 € / t$ excl. VAT. The structure of the total cost of bio-oil production from biomass over the project lifetime

\footnotetext{
1 Biomass residues from forest felling, deadwood, wood processing waste.
}

(20 years) includes, among others, the taxes payment and financial expenses. The main components of operational expenses are input product purchase (28\%) and wages payments (24\%).

Table 2. Technical parameters and OPEX of installation with capacity $500 \mathrm{~kg} / \mathrm{hour}$ (in EUR)

\begin{tabular}{cccc}
\hline Parameter & Value & Unit \\
\hline $\begin{array}{c}\text { Annual amount of processed } \\
\text { input product }\end{array}$ & 4200 & t/year \\
\hline Price of input product & 13 & $€ / \mathrm{t}$ \\
\hline Cost of input product & 51 & th. $€ /$ year \\
\hline Cost of electricity from the grid & 0.055 & $€ / \mathrm{kWh}$ \\
\hline $\begin{array}{c}\text { Annual cost of consumed } \\
\text { electricity }\end{array}$ & 16.2 & th. $€ /$ year \\
\hline Annual maintenance, repair & 3.6 & th. $€ /$ year \\
\hline Annual wages & 43.5 & th. $€ /$ year \\
\hline Annual amortization & 11.5 & th. $€ /$ year \\
\hline Total expenses & $\mathbf{3 3 . 5}$ & th. $€ /$ year \\
\hline Annual amount of produced & 2100 & $\mathrm{t} /$ year \\
\hline bio-oil & 45.5 & $€ / \mathrm{t}$ \\
\hline Tariff for selling of bio-oil & $\mathbf{2 6 . 5}$ & $\boldsymbol{\epsilon / t}$ \\
\hline Full cost of bio-oil & 1470 & $\mathrm{t} /$ year \\
\hline Annual amount of produced \\
biochar
\end{tabular}

To understand where the produced products among other fuel types are, the calculation of the cost of $1 \mathrm{MJ}$ of energy contained in bio-oil and biochar is performed according to the predefined "tariff for selling" of bio-oil and biochar (see Table 3). A comparison of $1 \mathrm{MJ}$ cost for different fuels is presented in Table 3.

Bio-oil and biochar are competitive in the Ukrainian market in comparison with fossil fuels by energy costs. The cost of $1 \mathrm{MJ}$ of energy contained in pyrolysis products is half as much as the indicator for heavy oil and natural gas (on the basis of commercial price), $15 \%$ less than for coal, and almost identical to that for wood chips with $40 \%$ moisture content. At the same time, bio-oil has a significant advantage over wood chips - its density is at least three times higher which significantly influences the logistical expenses of this fuel. 
Table 3. Comparison of energy costs from bio-oil, biochar and other fuel types

\begin{tabular}{|c|c|c|c|c|c|}
\hline \multirow{2}{*}{ Parameter } & \multicolumn{2}{|c|}{ Caloric value } & \multicolumn{2}{|c|}{ Cost excl. VAT } & \multirow{2}{*}{$\begin{array}{c}\text { Cost of energy unit } \\
€ € / M J\end{array}$} \\
\hline & $\mathrm{MJ} / \mathrm{kg}$ & $\mathrm{MJ} / \mathrm{m}^{3}$ & $€ / t$ & $€ /$ th. $\mathrm{m}^{3}$ & \\
\hline Natural gas (commercial price) & - & 34.1 & - & 239 & 7 \\
\hline Heavy oil & 38.3 & - & 272 & - & 7.1 \\
\hline Coal & 21.8 & - & 76 & - & 3.5 \\
\hline Wood chips (W = 40\%) & 10.2 & - & 30 & - & 3 \\
\hline Bio-oil (W = 40\%) & 14.7 & - & 45 & - & 3.1 \\
\hline Biochar & 25.1 & - & 76 & - & 3 \\
\hline
\end{tabular}

It should be also mentioned that in case only one pyrolysis product is sold and another is not, the cost of energy will respectively increase as all expenses will be relative to only one useful product. For example, for "bio-oil-only" mode, the cost of energy in bio-oil will increase to 6.1 EUR/MJ, which is still competitive with natural gas, but not with other fuel types. So it is extremely important to utilize and sell both biooil and biochar.

In "two-product-production" mode, the project could be economically feasible under conditions defined in Table 3. Using simple cash flow analysis method, the basic economic indicators could be calculated: simple payback period -3.5 years; discounted payback period - 3.9 years; internal rate of return (IRR) - 39\%; net present value (NPV) -0.25 million EUR; profitability index - 2.8 (Table 4).

Table 4. Basic economic indicators for bio-oil and biochar production

\begin{tabular}{ccc}
\hline Parameter & Value & Unit \\
\hline Simple payback period PBP & 3.5 & years \\
\hline Discounted payback period DPBP & 3.9 & years \\
\hline Internal rate of return IRR & 39 & $\%$ \\
\hline Net present value NPV & 0.25 & mill. $€$ \\
\hline Profitability index PI & 2.8 & - \\
\hline
\end{tabular}

The economic indicators are typical for bioenergy projects in Ukraine. To improve them it could be recommended to increase the size of the installation and use a cheaper input product. However, there is the upper limit for capacity increasing relative to the cone screw reactor technology application after which other pyrolysis technologies may be more competitive.

\section{CONCLUSIONS}

1. The considered fast ablative pyrolysis laboratory installation with a cone screw reactor after performance of all modifications and tunings demonstrates a high bio-oil yield of 51\% max. ( $44 \%$ average for a series of experiments), provides additional high quality output by-products (pyrogas and biochar, up to $60 \%$ each for some experiments) and has a number of advantages among other pyrolysis technologies, such as simple construction, easy scaling, low capital cost and high energy efficiency.

2. The energy efficiency of considered technology is $94 \%$ max. and $65 \%$ average with dependency on input product consumption and installation capacity factor (the higher consumption, the higher efficiency); the return of heat losses from feedstock system and utilization of produced pyrogas for reactor heating may provide $60 \%$ (on average) of the reactor heat demand which can also increase the energy efficiency (up to $90 \%$ average).

3. The assessment of economic indicators for scaled $500 \mathrm{~kg} /$ hour mobile fast pyrolysis installation shows that it is a commercially feasible project in case of selling of both bio-oil and biochar as products and utilization of pyrogas for reactor heating.

Received 1 February 2018 Accepted 20 February 2018

\section{References}

1. Bridgwater A. V. Review of fast pyrolysis of biomass and product upgrading. Biomass Bioenergy. 2012. Vol. 38. P. 68-94. 
2. Elliott D. C., Meier D., Oasmaa A., van de Beld B., Bridgwater A. V., Marklund M. Results of the international energy agency round Robin on fast pyrolysis bio-oil production. Energy Fuel. 2017. Vol. 31. P. 5111-5119.

3. Lédé J. Biomass fast pyrolysis reactors: a review of a few scientific challenges and of recommended research topics. Oil Gas Science and Technology - Rev. IFP Energies nouvelles. 2013. Vol. 68(5). P 801-814.

4. Funke A., Tomasi Morgano M., Leibold H., Dahmen N. Experimental comparison of fast and intermediate pyrolysis. Journal of Analytical and Applied Pyrolysis. 2017. Vol. 124. P. 504-514.

5. BTG-BTL technology: https://www.btg-btl.com/ en/technology

6. Zubenko V. I., Epik O. V. Obtaining of bio-oil from biomass through fast pyrolysis in the ablative screw reactor. Proceedings of the International Conference on the World Sustainable Energy Days (WSED), Wels, Austria, 28 February - 3 March 2017.

7. Luz F. C., Cordiner S., Manni A., Mulone V., Rocco V. Biomass fast pyrolysis in screw reactors: Prediction of spent coffee grounds bio-oil production through a monodimensional model. Energy Conversion and Management Energy Conversion and Management. 2018. Vol. 168. P. 98-106.

8. Lede J., Panagopoulos J., Li H. Z., Villermaux J. Fast pyrolysis of wood: direct measurement and study of ablation rate. Fuel. 1985. Vol. 64. Issue 11. P. 1514-1520.

9. Chiaramonti D., Oasmaa A., Solantausta Y. Power generation using fast pyrolysis liquids from biomass. Renewable and Sustainable Energy Reviews. 2007. Vol. 11. Issue 6. P. 1056-1086.

10. Zubenko V. I., Bashtovyi A. I., Antoshchuk T. O. Investigation of biomass fast pyrolysis in the ablative screw reactor. Proceedings of the 5th International Conference on Thermal Equipment, Renewable Energy and Rural Development, June 2-4, 2016, Golden Sands, Bulgaria. P. 21-26.
Vitalii Zubenko, Alex Epik, Viachceslav Antonenko

\section{GREITOS ABLIATYVIOSIOS PIROLIZÉS TECHNOLOGIJOS PLÉTRA IR OPTIMIZAVIMAS UKRAINOJE}

\section{Santrauka}

Straipsnyje pateikiami apibendrinti greitos ablatyviosios pirolizès laboratorinio i̇renginio (našumas 1-4 kg/h galutinio produkto) gamybos ir optimizavimo rezultatai. Analizuojami eksperimentų $(>60)$ duomenys, vertinama tam tikrų įvesties parametrų diapazono ịtaka naudojant bioalyvą ir poveiki produkcijos kokybiniams parametrams. Atliktas įrengimo režimų ir įvesties parametrų bioalyvos našumo didinimo skirtingiems biomasès tipams optimizavimas. Nustatyta, kad trijų išeinančių produktų santykis ne visada yra optimalus didinant bioalyvos išeigą pagal produkcijos energetinę vertę. Didžiausia pasiekta bioalyvos išeiga yra $51 \%$, o vidutinis lygis - $44 \%$ (pagal ịvedamų produktų masę). Nustatyta, kad galutinè bioalyvos išeiga labiausiai priklauso nuo temperatūros reaktoriuje, biomasès dalelių buvimo reaktoriuje ir biomasės frakcijos. Pirolizès šalutinių produktų (pirolizès dujų ir bioanglies) masès pasiskirstymas priklauso nuo pradinès biomasès drègmès ir bioalyvos kondensacijos proceso. Irenginio energijos balansas rodo, kad pirolizés proceso vidutinis efektyvumas yra 65 \% (daugiausia $98 \%$ ) ir gali būti padidintas iki 90 \% naudojant paprastą įrenginio rekonstrukciją. Remiantis gautais laboratoriniais duomenimis, įrenginio mastelio keitimo procesas vykdytas tobulinant komercini prototipą, kurio našumas siekia $50 \mathrm{~kg} / \mathrm{h}$. Remiantis gautais techniniais duomenimis, atliktas bioalyvos ir bioanglies gamybos su didelio masto mobiliuoju įrenginiu ekonominių rodiklių vertinimas, parodantis gerą įrenginio veikimo ekonomiškumą.

Raktažodžiai: greita abliatyvioji pirolizè, sraigtinis reaktorius, bioalyva, bioanglis, pirolizès dujos, pirolizès energijos naudojimo efektyvumas 